\title{
Corporate Culture Dimensions Associated With Organizational Commitment: An Empirical Study
}

Nabeel Sawalha, Gulf University for Science \& Technology, Kuwait Michel Zaitouni, Gulf University for Science \& Technology, Kuwait Adil ElSharif, Gulf University for Science \& Technology, Kuwait

\begin{abstract}
This study investigated the impact of corporate culture dimensions (empowerment, competence development, fair rewards and information sharing) on the affective, continuance, and normative organizational commitment in the banking sector in Kuwait. An empirical analysis was conducted across permanent, full-time and part-time employees (managers and non-managers) of five large private banks in Kuwait $(n=398)$. Both Exploratory Factor Analysis $(E F A)$ and hierarchical regression analyses were used to draw the relationship between these variables.
\end{abstract}

The results showed that sixty percent of variables confirmed previous studies and the remaining ones, surprisingly, were in conflict with previous studies due to some specific Kuwaiti cultural factors. Researchers are challenged to delve deeper into the complex relationship between variables since many of the studies have been conducted in Western societies; thus, the findings can be useful in future comparative studies. A replication of this study in other Arab countries with either the same corporate culture dimensions developed earlier or extended ones could reveal whether these results are country-specified or may be generalized to other countries.

Keywords: Corporate Culture; Banking Sector; Empowerment; Competence Development; Fair Rewards; Information Sharing; Organizational Commitment

\section{INTRODUCTION}

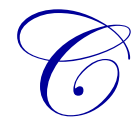

onsidered as a complex and integral element of an organization, the concept of corporate culture, as a management tool, is still frequently adapted to suit the organization's purpose (Ashkanasy et al., 2000).

There is a general consensus among researchers on the definition of corporate culture as "the pattern of shared values and beliefs that affect the way in which things are done". For the purpose of creating a committed workforce, organizations are trying to promote a corporate culture of commitment to the organization's value system and achievement of the defined performance outcome (Welch \& Welch, 2006).

Ritchie (2000) pointed out that corporate culture has the potential to influence the organization's desired outcomes such as commitment, productivity, performance and ethical behavior. Many scholars (e.g., Ulrike de Brentani and Elko J. Kleinschmidt (2004) propose that certain dimensions that define the organization's behavioral environment, that is its culture and commitment, can impact the outcome of these complex and risky endeavors; hence, the need has arisen for appropriate corporate culture dimensions to be developed in order to support the scope of organizational commitment. A clear synergy appears between these dimensions as they are integrated under the umbrella of a strong and appropriate corporate culture for exploitation.

A framework comprising elements of corporate culture constructs and influences, such as empowerment, competence development, fair rewards and information sharing, has been identified and customized to the relevant corporate culture. 
In this study, the aim is to determine the viability of corporate culture dimensions as determinants of employees' commitment to their banks in Kuwait. Firstly we expose the relationship between corporate culture and organizational commitment in general. Secondly, we examine the relationship between each dimension of corporate culture with the three types of commitment: affective, continuance and normative in an attempt to integrate the corporate culture concept as an effective managerial tool that affects the organization's desired outcomes.

\section{LITERATURE REVIEW}

Although literature reveals little empirical research on the link between the organizational culture and commitment, the relationship has been theoretically established. However, the organizational culture dimensions have been defined differently by different researchers. Two studies by McKinnon et al. (2003) and Taylor et al. (2008) found a relationship between culture (respect for people, team orientation, completion of work tasks) and organizational commitment. Studies by Garr (1998), Rousseau (1990), Vandenberghe and Peiro (1999), Finegan (2000), and Abbott et al. (2005), on the other hand, have established a link between affective and normative commitment and what they call "constructive" culture. This implies participation in the decision-making, achievement and self-actualization promotion, empowered employment, quality interpersonal communication, teamwork, and socially supportive environment for the growth of the organization's members. Meyer and Allen (1997) also indicated that members who view their organization as constructive will be unlikely to have the intention to leave; that establishes a link between organizational values and normative and continuance commitment.

\subsection{Empowerment and organizational commitment}

As organizations embrace and practice higher power sharing at the level of defining, organizing, and conducting task decisions, empowering employees with responsibilities and discretion to influence work outcomes would create a greater level of employee ownership, support, and trust and as a result, a greater development of high commitment and intention to stay among members of the organization (Eisenberger et al., 1986; Leana \& Florkowski, 1992; Appelbaumet al., 2000; Tsui et al., 1995; Meyer \& Smith, 2000; Allen et al., 2003; Eby et al., 1999).

Carson et al. (1999) suggested that employees, "dually committed" to their career and organizations, have shown high job satisfaction, low intention to leave, and more empowerment. Sarkar (2009) also indicated that empowerment can increase accountability, individual involvement with the organization's values and goals, creativity, and a feeling of importance in taking decisions as a result of commitment.

In a study of employees in the public sector of Korea, Joo \& Shim (2010) indicated that empowerment had positively influenced organizational commitment in addition to the education level as a moderator among other demographics like gender, age, hierarchical level, and length of employment. In another study involving 40 companies in the technology field in Taiwan, Kuo et al. (2010) showed similar results linking empowerment and organizational commitment.

A recent study by Yang (2011) involving 172 restaurant employees in Taiwan revealed that high involvement practices like empowerment, competence development, recognition, fair rewards, and information sharing were positively and directly related to affective commitment.

Smeenk et al. (2006) also conducted a study on 412 Dutch faculty employees to draw a relationship between HR practices and organizational commitment. The results showed positive relationships between two factors of empowerment (decentralization and participation) and affective, continuance, and normative commitment. Therefore, empowerment conflict might arise when superiors exert the maximum level of control by imposing the organization's goals and values for lower level employees to follow with a minimum or no involvement in setting organizational goals. Any initiative by the employees will be objected to or resisted by superiors in order to maintain that high level of control (Janssen, 2004).

Another investigation by Bhatnagar (2005) also revealed a positive relationship between psychological empowerment (meaning, competence, self-determination, and impact) and affective, continuance, and normative commitment. 
Workplace empowerment can also lead to trust building, work satisfaction and, as a result, an organizational affective commitment. These results were obtained from a study by Laschinger et al., (2001) surveying 412 staff nurses in a central Canadian province.

Culture can also play a role in the relationship between organizational commitment and empowerment.

H1a: Empowerment is positively and significantly associated with affective commitment

H1b: Empowerment is positively and significantly associated with continuance commitment

H1c: Empowerment is positively and significantly associated with normative commitment

\subsection{Competence development and organizational commitment}

Employee training investment by the organization is intended to send a commitment message to its employees that individual development is a valued goal of the organization (McElroy, 2001). An employee's commitment might be influenced more by the message HRM practices convey to the employee than by the practices themselves (Guzzo and Noonan, 1994; Iles et al., 1990). Training is used to enhance specific skills and correct performance issues to empower employees with skills needed for the current and future job requirement (GomezMejia et al., 1995; Gold, 2001; Wood and De Menezes, 1998).

The building of employees' skills to perform their job would establish a higher level of confidence as well as influencing the employees' perception that the organization values their presence, therefore establishing employees' long-term commitment (Smith, 1995).

In addition to the commitment positive link to profit sharing, bonuses, and pay, Landau and Hammer (1986) indicated that $\mathrm{OC}$ is enhanced by offering employees "advancement opportunities" within the organization.

Koys (1988 \& 1991) found that workers' commitment is related directly to their faith in the intention of the HRM practices of the organization to keep skilled employees and treat them fairly. An employee's skill, training, and personal development practices, including job redesign/enrichment, have shown positive results in building an employee's confidence level, a sense of control, and identification of their work, resulting in an affective commitment (Meyer et al., 2004).

Additionally, Armstrong-Stassen and Schlosser (2008) and Malik et al., (2011) have linked development orientation to an investment in development climate which asserted a positive and significant relationship on affective commitment.

In examining the impact of career growth on organizational commitment by surveying 961 employees in 10 cities in China, Weng et al.'s (2010) research results showed a significant and positive link between the four dimensions of growth (career goal progress, professional ability development, promotion speed, remuneration growth) and affective, continuance, and normative commitment.

Ahmad \& Bakar (2003) demonstrated that creating a training environment linked to the overall benefits of training generated a positive correlation with all types of organizational commitment (affective, normative, and continuance). Consistent with these results, Al-Emadi and Marquardt (2007) also confirmed a positive and significant relationship between the career benefits of a training climate and affective, continuance, and normative commitment.

In another research investigating the relationship between training and organizational commitment, outcomes showed a positive and significant relationship with affective and normative commitment, while the continuance commitment showed a negative link (Bartlett, 2001). 
Meyer and Allen (1997) asserted that once the employee realizes the importance of training and the skills he can build for his career, he will develop an obligation (normative commitment) to stay at the job.

H2a: Competence development is positively and significantly associated with affective commitment

H2b: Competence development is positively and significantly associated with continuance commitment

H2c: Competence development is positively and significantly associated with normative commitment

\subsection{Fair rewards and organizational commitment}

The ability to manage a successful reward system is one of the most fundamental issues and concerns for many organizations. It is imperative to know how money can play a role in motivating employees (Thorpe and Homan, 2000).

Previous studies on the influence of human resource practices on organizational commitment revealed a causal relationship between rewards and benefits and commitment. To achieve organizational goals, a reward system can be used as a tool to develop a suitable organizational culture that would boost an employee's motivation and commitment (Pfeffer, 1994, 1995, 1998; Mondy et al., 2002). Many employees look at pay allocation with suspicion and view it as unfair practice among peers (Trevor et al., 1997), which explains why the relationship between pay and commitment was found insignificant in other studies (Motowildo, 1988; Currall et al., 2005; Tekleab et al., 2005; Trevor et al., 1997).

Reward practices would link employees' performance level to the expected rewards. Therefore, management should implement a "performance-contingent" reward system to predict an employee's output and performance commitment in the organization (Gagne' and Deci, 2005).

The equity theory suggested that employees weigh their effort (output) against the compensation they receive. If viewed as a fair package, employees see justice is being provided, become satisfied, and therefore commit to a long-term relationship in the organization (Adams, 1965). Multiple studies (Pillai et al., 1999; Folger \& Konovsky, 1989; Gopinath \& Becker, 2000) have confirmed this relationship between fair compensation and organizational commitment.

When employees perceive, believe, and understand that the pay program intends to provide "internal pay equity", they tend to have high organizational commitment (Stum, 1999).

Attractive benefits packages are viewed by employees as indications that the organization cares and supports its employees, resulting in the development of a strong affective commitment and the belief that the loss of such package would be costly. This feeling results in a greater experience of continuance commitment, indebted attachment to the workplace, leading in turn to a stronger normative commitment (Meyer and Allen, 1997). More and more research revealed a positive link between benefit packages and employee commitment (Grover and Crooker, 1995).

Paik et al., (2007) examined the effects of perception gaps in compensation between home country employees and expatriates. Results indicated that the wider the compensation gap, the lower the affective commitment, revealing a significant relationship with affective commitment, while continuance commitment was not impacted at all.

A survey conducted by Malhotra et al. (2007) on four call centers of a major retail bank in the UK revealed that extrinsic organizational rewards like promotional opportunities, and intrinsic rewards like role clarity, participation in decision making, and autonomy had a significant and positive impact on affective commitment. At the same time, pay satisfaction had a significant and a positive effect on continuance commitment, while the normative commitment was positively and significantly influenced by autonomy, feedback, and training (intrinsic rewards), and satisfaction with the fringe benefits' package offered by the organization as an extrinsic reward. 
Consistent with these results, Landau \&Hammer (1986) indicated that OC commitment also showed a positive link with the practices of profit sharing, bonuses, and pay.

H3a: Fair rewards are positively and significantly associated with affective commitment

H3b: Fair rewards are positively and significantly associated with continuance commitment

H3c: Fair rewards are positively and significantly associated with normative commitment

\subsection{Information sharing and organizational commitment}

The relationship between information sharing and organizational commitment has been identified by many researchers for many years. Management adopts information sharing as an important and effective tool to enhance and strengthen an employee's commitment to the organization. The information-sharing process involves the way the organization distributes and receives knowledge among the organization's members in order to strengthen the decision-making process. This practice ensures that employees are being recognized as part of the decision-making process and management are treating their views or opinions with respect.

Paré \& Tremblay (2007) investigated the relationship between the "high-involvement human resources practices and the turnover intention" in the Canadian Information Processing Society in Quebec. A sample of 394 participants showed that information sharing was positively related to the employees' intention to stay. By creating a work climate that fosters information sharing and involving employees before decision taking, management would build a healthy environment in which members' self-confidence and recognition of their ideas leads to mutual respect and in turn to an affective commitment (Campbell, 2000).

O'Neill and Adya (2007) indicated that in a culture such as that of the Chinese, where people are communitarians and value harmony, knowledge sharing is a common practice among group members. Their study confirms another research by Wasko and Faraj (2005) who linked knowledge sharing to employees' obligation to satisfy social orientation and community characters and interests, therefore, generating a higher organizational commitment.

Meyer \& Allen (1997) asserted that information sharing is positively correlated to affective commitment by building the trust between management and employees and workers' self-worthiness. Aligned with Meyer \& Allen (1997), Trombetta \& Rogers (1988), Thornhill et al. (1996), and Guzley (2001) confirmed this relationship, stating that open and transparent communication along with access to adequate information and participative decisionmaking involvement builds positive affective commitment. On the other hand, fostering a downward and upward flow of communication among different levels of the organization would influence the level of an employee's commitment and comfort in the workplace (Young and Worchel, 1998).

Parker and Kyi (2006) and Postames et al. (2001) shed light on what is called vertical \& horizontal communication and information sharing. Vertical information flows from top management to employees at the lower level, while horizontal information is about social communication. Both findings showed that only vertical information sharing reveals a positive and significant association with affective organizational and performance commitment. By involving employees with this knowledge sharing, management would build a healthy environment in which members' self-confidence, recognition of their ideas, and a feeling of control over what they are doing leads to mutual respect, which positively impacts the employee's level of commitment (Leana and Florkowski, 1992; Pfeffer and Veiga, 1999; Cook, 1994; Campbell, 2000). In the meantime, sharing information does not mean sacrificing trade secrets. Management has to decide what type and how much information to share with employees. Usually upper level management possesses more information than lower level employees. An organization would not share information if "it carries high efficiency cost" (Ronde, 2001).

Aiming to explore the impact of human resource management (HRM) practices in Swiss small-to-medium enterprises (SMEs) on employees' commitment, Giauque et al. (2010) used data from a survey of over 198 knowledge workers. It was found that information sharing through decision-making participation has a significant 
correlation to a level of 0.05 with the affective and normative organizational commitment. Continuance commitment, on the other hand, does not have any significant relation.

Buck and Watson (2002) also examined the influence of HRM strategies on organizational commitment using data on human resources practices at 34 public institutions of higher education in the United States. Statistical analysis found significant and positive relationships between the level of information sharing through the decentralized decision-making and affective commitment, while continuance and normative commitment showed an insignificant relationship.

Wong et al. (2009) concluded that knowledge-sharing practices in Hong Kong's ICT companies promoted and strengthened organizational commitment. It was found that knowledge-sharing practices had a positive and significant impact on affective, continuance, and normative commitment. Kelloway and Barling's (2000) also confirmed that "the willingness to donate knowledge" is positively related to affective commitment.

H4a: Information sharing is positively and significantly associated with affective commitment.

H4b: Information sharing is positively and significantly associated with continuance commitment.

H4c: Information sharing is positively and significantly associated with normative commitment.

\section{METHODOLOGY}

\subsection{Procedures}

A total of 1000 questionnaires were distributed to various levels of employees of the participant banks via the internal mail system through the HR manager. Each questionnaire included a covering letter explaining the aim of the study and its implications for the banking sector in Kuwait in terms of employees' commitment. For the purpose of maintaining confidentiality and anonymity, the completed questionnaires were returned to the HR manager via the internal mail system. In total, 460 employees responded, generating an overall usable response rate of $39.8 \%$ (62 non-usable responses).

\subsection{Sample proportion}

The surveyed participants were permanent, full-time and part-time employees (managers and nonmanagers) of five large private banks in Kuwait: National Bank of Kuwait (NBK), Gulf Bank, Kuwait Finance House (KFH), Al-Ahly Bank of Kuwait (ABK), and the Bank of Kuwait and Middle East (BKME). Each bank has more than 500 employees. There was a fairly close split between male (56.55\%) and female (43.5\%) participants and a fair distribution among age groups (28\% between $21-25$ years, 52\% between $26-35$ years, $13 \%$ between $36-45$ years, $5.5 \%$ between $46-55$ years, $0.9 \%$ between $56-60$ years and $0 \%$ over 65 years). The sample was relatively young in terms of age since the majority $(80 \%)$ was less than 35 years old. Regarding the educational level, the majority of respondents (86\%) held a diploma and higher degree. Furthermore, $48.3 \%$ of respondents had been in their position for five years and above, and $18.3 \%$ of respondents had been working in the present organization for over five years. In terms of positions, 262 respondents were non-managerial $(66 \%)$; the remaining respondents were managerial (34\%). Table 1 details the sample proportion with respect to gender, age, educational level, job tenure, and organizational tenure. 
Table 1 Sample frequencies

\begin{tabular}{|c|c|c|}
\hline & & Sample $(n=398)$ \\
\hline \multicolumn{3}{|c|}{ Gender } \\
\hline - & Male & 56.5 \\
\hline - & Female & 43.5 \\
\hline \multicolumn{3}{|c|}{ Age } \\
\hline- & $21-25$ & 28.4 \\
\hline - & $26-35$ & 52.2 \\
\hline - & $36-45$ & 13 \\
\hline - & $46-55$ & 5.5 \\
\hline - & $56-60$ & 9 \\
\hline - & above 65 & 0 \\
\hline \multicolumn{3}{|c|}{ Edu. Level } \\
\hline- & HS & 12.6 \\
\hline - & Diploma & 14.4 \\
\hline - & Degree & 71.7 \\
\hline- & Post Grad. & 1.3 \\
\hline \multicolumn{3}{|c|}{ Job Tenure } \\
\hline - & $0-5$ & 51.7 \\
\hline- & $6-10$ & 37.11 \\
\hline- & Above 10 & 11.19 \\
\hline \multicolumn{3}{|c|}{ Org. Tenure } \\
\hline- & $0-5$ & 81.7 \\
\hline- & $6-10$ & 13.42 \\
\hline - & Above 10 & 4.88 \\
\hline \multicolumn{3}{|c|}{ Position level } \\
\hline - & Mgr & 34 \\
\hline- & Non-Mgr & 66 \\
\hline
\end{tabular}

\subsection{Measures}

\subsubsection{Corporate culture dimensions}

The corporate culture dimensions were measured with a scale for empowerment, competence development, fair rewards, and information sharing. The intended outcomes included affective, continuance, and normative commitment. Tremblay et al. (1997) assessed all corporate culture dimensions but one, using a five-point Likert scale ( $1=$ strongly disagree to $5=$ strongly agree), indicating the extent to which the four dimensions were used in their organization. The first corporate culture dimension, labeled 'empowerment', included three items measuring the level of autonomy and freedom employees have regarding the way they carry out their work (Cronbach alpha $=0.698$ ). The second dimension, labeled 'competence development', included six items measuring employees' development skills and their chances for promotion (Cronbach alpha $=0.855$ ). The third dimension, labeled 'fair rewards', included four items measuring employees' perception of their compensation level (Cronbach alpha $=0.805$ ). The last dimension, labeled 'information sharing', adopted from a survey done by Lawler et al. (1992), included six items measuring employees' involvement in the company's decision-making process at all levels. The resulting Cronbach alpha for information sharing was 0.879 . 


\subsubsection{Organizational commitment}

The three dimensions of employee organizational commitment were assessed using the scale developed by Meyer et al. (1993). The affective commitment scale included six items measuring the emotional reasons for which employees would stay in the organization. The resulting Cronbach alpha for affective commitment is 0.846 . The continuance commitment scale included five items measuring the economic reasons for which employees would stay in the organization. The resulting Cronbach alpha for continuance commitment is 0.780 . The normative commitment scale included three items measuring the ethical and moral reasons for which employees would stay in the organization. The resulting Cronbach alpha for normative commitment is 0.583 .

\subsection{Factor analysis}

For the purpose of data reduction, in order to create smaller summary variables sets and to construct a base understanding of the conceptual framework of the corporate culture dimensions-commitment phenomena, exploratory factor analysis has been conducted in this study. We used two criteria for determining the appropriateness of the factor model: Eigenvalue (1.00) and communality (0.20). Based on the assumption that the factors are correlated, we used the direct oblique rotation to rotate the factor matrices to a simple structure. The results for factor analyses (corporate culture dimensions), Cronbach's alpha, and the total explained variance are presented in Table 2 .

Table 2 Exploratory factor analys is for Corporate culture dimensions



Extraction Method: Principal Component Analysis; Rotation Method: Oblimin with Kais er Normalization; * Factors loading less than 0.5 are not reported 
Another set of exploratory factor analyses has been used for the three dimensions of organizational commitment, excluding all factors loading less than 0.5. As is often the case for all measures, we used the direct oblique rotation since the components of commitment have been found correlated (Meyer et al., 2002). Table 3 shows the three subscale items of commitment, Cronbach's alpha, and the total explained variance, omitting factors loading less than 0.05 .

Table 3 Exploratory factor analys is for Organizational Commitment

\begin{tabular}{lc}
\hline & 1 \\
\hline Affective Commitment & \\
& \\
1- I would be very happy to spend the rest of my career with this organization & 0.804 \\
2- I really feel as if this organization's problems are my own & 0.819 \\
3- This organization has a great deal of personal meaning for me & 0.739 \\
4- I would feel guilty if I left my organization now & 0.591 \\
5- This organization deserves my loyalty & 0.631 \\
6. This organization deserves my loyalty & 0.665
\end{tabular}

\section{Continuance Commitment}

0.78

1- It would be very hard for me to leave my organization right now even if I wanted to

2- Too much in my life would be disrupted if I decided I wanted to leave my organization now

3- Right now, staying with my organization is a matter of necessity as much as desire

4- One of the few negative consequences of leaving this organization would be the scarcity of available job alternatives

5- One of the major reas ons I continue to work for this organization is that leaving would require considerable personal sacrifice- another organization may not match the verall benefits I have here

\section{Normative Commitment}

1. If I got another offer for a better job elsewhere, I would not feel

It was right to leave my organization

2- I was taught to believe in the value of remaining loyal to one organization

3 - Things were better in the days when people stayed with one organization for most of their career

Total explained variance: $57.727 \%$

$37.38 \%$
0.706

0.694

0.766

0.654

Extraction Method: Principal Component Analysis; Rotation Method: Oblimin with Kaiser Normalization; * Factors loading less than 0.5 are not reported

\section{RESULTS}

Table 4 shows the means, standard deviations and Cronbach's alpha coefficients of the variables. A series of hierarchical regression analyses were conducted to examine the impact of corporate culture dimensions on affective, continuance and normative commitment (see Tables 5, 6, and 7). The variables were entered into the regression equation in two steps. The control variables were entered first. The corporate culture dimensions were entered

second. 
Table 4 Means, Standard Deviation, Reliabilities, and Correlations ( $\mathrm{N}=340)$

\begin{tabular}{|c|c|c|c|c|c|c|c|c|c|c|c|c|c|c|c|c|}
\hline Variables & Mean & SD & 1 & 2 & 3 & 4 & 5 & 6 & 7 & 8 & 9 & 10 & 11 & 12 & 13 & 14 \\
\hline 1.Gender & 1.400 & 0.491 & $(\ldots)$ & & & & & & & & & & & & & \\
\hline 2.Age & 1.980 & 0.845 & $-.189 * *$ & $(\ldots)$ & & & & & & & & & & & & \\
\hline 3.Education Level & 2.800 & 0.712 & -0.089 & -0.089 & $(\ldots)$ & & & & & & & & & & & \\
\hline 4.Positional Tenure 1 & 0.514 & 0.500 & $.142 * *$ & $-.622 * *$ & -0.062 & $(\ldots)$ & & & & & & & & & & \\
\hline 5.Positional Tenure 2 & 0.241 & 0.428 & -0.065 & 0.071 & -0.049 & $-.579 * *$ & $(\ldots)$ & & & & & & & & & \\
\hline 6.0rganizational Tenure 1 & 0.815 & 0.389 & 0.037 & $-.504 * *$ & 0.039 & $.458 * *$ & -0.035 & $(\ldots)$ & & & & & & & & \\
\hline 7.0rganizational Tenure 2 & 0.135 & 0.342 & 0.014 & $.319^{* *}$ & 0.007 & $-.381 * *$ & $.097^{*}$ & $-.827 * *$ & $(\ldots)$ & & & & & & & \\
\hline 8.Empowerment & 3.196 & 0.863 & -0.049 & $.098^{*}$ & 0.087 & 0.017 & -0.092 & -0.048 & 0.006 & -0.698 & & & & & & \\
\hline \multicolumn{17}{|l|}{ 9.Competence } \\
\hline Development & 3.487 & 0.896 & 0.056 & 0.070 & 0.043 & 0.013 & $-.118^{*}$ & -0.056 & 0.016 & $.595 * *$ & -0.855 & & & & & \\
\hline 10.Fair Rewards & 2.859 & 0.923 & -0.022 & $.149 * *$ & 0.066 & $-.111^{*}$ & -0.017 & $-.103^{*}$ & $.132 * *$ & $.432 * *$ & $.471^{* *}$ & -0.805 & & & & \\
\hline 11.Information Sharing & 3.342 & 0.931 & $.138 *$ & 0.023 & 0.056 & 0.065 & $-.104 *$ & -0.043 & 0.045 & $.517 * *$ & $.625^{* *}$ & $.382 * *$ & -0.879 & & & \\
\hline 12.Affective Commitment & 3.277 & 0.964 & $-.139 *$ & $.220 * *$ & 0.049 & $-.134 * *$ & 0.015 & $-.154 * *$ & $.099 *$ & $.455^{* *}$ & $.438 * *$ & $.406 * *$ & $.435^{* *}$ & -0.846 & & \\
\hline $\begin{array}{l}\text { 13.Continuance } \\
\text { commitment }\end{array}$ & 3.184 & 0.904 & -0.093 & -0.041 & 0.001 & 0.024 & 0.011 & 0.050 & -0.040 & $.147 * *$ & $.238 * *$ & $.238 * *$ & $.240 * *$ & $.465^{* *}$ & -0.780 & \\
\hline 14..Normative commitment & 3.266 & 0.771 & -0.021 & -0.011 & -0.026 & 0.046 & -0.015 & 0.006 & 0.008 & $.163^{* *}$ & $.104^{*}$ & 0.060 & $.250 * *$ & $.335^{* *}$ & $.368 * *$ & -0.583 \\
\hline
\end{tabular}

Notes: Cronbach a coefficients appear in parentheses 
The first set of regression analyses was conducted with affective commitment as the dependent variable. The results provide support for the hypotheses: H1a, H3a and H4a. (Overall model: F=28.988, P<.001; adjusted Rsquare $=.348$.) As expected, empowerment, fair rewards, and information sharing were positively and significantly related to affective commitment $(\mathrm{B}=.19, \mathrm{P}<.001 ; \mathrm{B}=.18, \mathrm{P}<.001$; and $\mathrm{B}=.26, \mathrm{P}<.001)$. In conflict with previous studies, H2a was not supported. No significant relationship was found between competence and affective commitment $(\mathrm{H} 2 \mathrm{a})$. The results of these analyses are presented in Table 5.

Table 5 The Hierarchical Regression Analyses for Corporate Culture Dimensions on Affective Commitment

\begin{tabular}{|c|c|c|c|c|c|c|c|c|}
\hline $\begin{array}{l}\text { Independent } \\
\text { variables }\end{array}$ & $\begin{array}{c}\text { Unstandardized } \\
\beta\end{array}$ & $\begin{array}{c}\text { Standard } \\
\text { error }\end{array}$ & $\begin{array}{c}\text { Standardized } \\
\beta\end{array}$ & R Square & $\begin{array}{l}\text { Adjusted } \\
\text { R Square }\end{array}$ & $\begin{array}{c}\text { R Square } \\
\text { Change }\end{array}$ & F change & $\begin{array}{l}\text { Sig.F } \\
\text { change }\end{array}$ \\
\hline Model 1 & & & & 0.099 & 0.076 & 0.099 & 4.226 & 0.000 \\
\hline Gender & -0.113 & 0.113 & -0.059 & & & & & \\
\hline Age & 0.196 & 0.102 & 0.171 & & & & & \\
\hline Education Level & 0.078 & 0.091 & 0.051 & & & & & \\
\hline \multicolumn{9}{|l|}{ Positional } \\
\hline \multicolumn{9}{|l|}{ Tenure } \\
\hline $0-5$ & -0.136 & 0.213 & -0.073 & & & & & \\
\hline$>5$ & 0.131 & 0.187 & 0.061 & & & & & \\
\hline \multicolumn{9}{|l|}{ Org.Tenure } \\
\hline $0-5$ & -0.301 & 0.313 & -0.117 & & & & & \\
\hline$>5$ & -0.145 & 0.321 & -0.049 & & & & & \\
\hline Model 2 & & & & 0.374 & 0.348 & 0.275 & 28.988 & 0.000 \\
\hline Gender & -0.213 & 0.098 & -0.112 & & & & & \\
\hline Age & 0.105 & 0.087 & 0.092 & & & & & \\
\hline Education Level & 0.009 & 0.077 & 0.006 & & & & & \\
\hline \multicolumn{9}{|l|}{ Positional } \\
\hline \multicolumn{9}{|l|}{ Tenure } \\
\hline $0-5$ & -0.231 & 0.18 & -0.123 & & & & & \\
\hline$>5$ & 0.158 & 0.158 & 0.074 & & & & & \\
\hline \multicolumn{9}{|l|}{ Organizational } \\
\hline \multicolumn{9}{|l|}{ Tenure } \\
\hline $0-5$ & -0.118 & 0.264 & -0.046 & & & & & \\
\hline$>5$ & -0.145 & 0.271 & -0.045 & & & & & \\
\hline Empowerment & 0.197 & 0.071 & $.184^{* * * *}$ & & & & & \\
\hline $\begin{array}{l}\text { Competence } \\
\text { Development }\end{array}$ & 0.068 & 0.074 & 0.063 & & & & & \\
\hline Fair Rewards & 0.183 & 0.059 & $.175^{* * *}$ & & & & & \\
\hline $\begin{array}{l}\text { Information } \\
\text { Sharing }\end{array}$ & 0.267 & 0.065 & $.265^{* * *}$ & & & & & \\
\hline
\end{tabular}

Notes: $* \mathrm{p}<.05 ; * * \mathrm{p}<.01 ; * * * \mathrm{p}<.001$ 
The overall model was significant when continuance commitment was entered as the dependent variable. The results provide support for the hypotheses H3b and H4b. (Overall model: F=5.272, P<.001; adjusted Rsquare $=.040$.) The relationships between continuance commitment and fair rewards and information sharing were significant $(\mathrm{B}=.14, \mathrm{p}<.01 ; \mathrm{B}=.17, \mathrm{P}<.01)$. However, hypothesis $\mathrm{H} 2 \mathrm{~b}$ was not supported. No significant relationship was found between continuance commitment and competence development. Surprisingly, in conflict with some previous studies (Laschinger et al., 2001; Liu et al., 2007), a negative relationship was found between empowerment and continuance commitment $(\mathrm{H} 1 \mathrm{~b})(\mathrm{B}=.16, \mathrm{p}<.01)$. The results of these analyses are presented in Table 6 .

Table 6 Results of the Hierarchical Regression Analyses for Corporate Culture dimensions on Continuance Commitment

\begin{tabular}{|c|c|c|c|c|c|c|c|c|}
\hline $\begin{array}{l}\text { Independent } \\
\text { variables }\end{array}$ & $\begin{array}{c}\text { Unstandardized } \\
\beta\end{array}$ & $\begin{array}{c}\text { Standard } \\
\text { error }\end{array}$ & $\begin{array}{c}\text { Standardized } \\
\beta\end{array}$ & R Square & $\begin{array}{l}\text { Adjusted } \\
\text { R Square }\end{array}$ & $\begin{array}{l}\text { R Square } \\
\text { Change }\end{array}$ & F change & $\begin{array}{l}\text { Sig.F } \\
\text { change }\end{array}$ \\
\hline Model 1 & & & & 0.007 & .018 & 0.007 & 0.279 & 0.982 \\
\hline Gender & -0.081 & 0.11 & -0.044 & & & & & \\
\hline Age & -0.042 & 0.098 & -0.038 & & & & & \\
\hline Education Level & -0.023 & 0.088 & -0.016 & & & & & \\
\hline Positional Tenure & . & & & & & & & \\
\hline $0-5$ & 79 & 0.198 & 0.044 & & & & & \\
\hline$>5$ & -0.027 & 0.177 & 0.072 & & & & & \\
\hline \multicolumn{9}{|l|}{ Organizational } \\
\hline \multicolumn{9}{|l|}{ Tenure } \\
\hline $0-5$ & -0.061 & 0.284 & -0.025 & & & & & \\
\hline$>5$ & -0.027 & 0.293 & -0.01 & & & & & \\
\hline Model 2 & & & & 0.077 & 0.04 & 0.07 & 5.272 & 0.02 \\
\hline Gender & -0.158 & 0.109 & -0.087 & & & & & \\
\hline Age & -0.041 & 0.096 & -0.038 & & & & & \\
\hline Education Level & -0.025 & 0.086 & -0.018 & & & & & \\
\hline \multicolumn{9}{|l|}{ Positional Tenure } \\
\hline $0-5$ & 0.104 & 0.193 & 0.059 & & & & & \\
\hline$>5$ & 0.175 & 0.173 & 0.086 & & & & & \\
\hline \multicolumn{9}{|l|}{ Organizational } \\
\hline \multicolumn{9}{|l|}{ Tenure } \\
\hline $0-5$ & -0.054 & 0.276 & -0.022 & & & & & \\
\hline$>5$ & -0.118 & 0.287 & -0.042 & & & & & \\
\hline Empowerment & -0.164 & 0.081 & $-.156 * *$ & & & & & \\
\hline $\begin{array}{l}\text { Competence } \\
\text { Development }\end{array}$ & 0.095 & 0.084 & 0.094 & & & & & \\
\hline Fair Rewards & 0.149 & 0.067 & $.148 * *$ & & & & & \\
\hline $\begin{array}{l}\text { Information } \\
\text { Sharing }\end{array}$ & 0.175 & 0.073 & $.183 * *$ & & & & & \\
\hline
\end{tabular}

Notes: $* \mathrm{p}<.05 ; * * \mathrm{p}<.01 ; * * * \mathrm{p}<.001$

Also, the overall model was significant when normative commitment was entered as the dependent variable ( $\mathrm{F}=8.451, \mathrm{P}<.001$; adjusted $\mathrm{R}$-square=.084). Information sharing was positively related to normative commitment $(\mathrm{H} 4 \mathrm{c})(\mathrm{B}=.029, \mathrm{p}<.001)$. Hypotheses $\mathrm{H} 1 \mathrm{c}$ and $\mathrm{H} 2 \mathrm{c}$ were not supported. In conflict with previous studies (Smeenk et al., 2006), the relationships between normative commitment and empowerment and competence development were found to be non-significant $(\mathrm{B}=-.004$ for empowerment; $\mathrm{B}=-.053$ for competence development, and $\mathrm{B}=-.049$ for fair rewards). Nonetheless, in contradiction with previous studies (Caldwell et al., 1990; Gellatly et al., 2009), a negative 
relationship was found between fair rewards and normative commitment $(\mathrm{B}=.15, \mathrm{p}<.001)$. The results of these analyses are presented in Table 7.

Table 7 Results of the Hierarchical Regression Analyses for Corporate Culture dimensions on Normative Commitment

\begin{tabular}{|c|c|c|c|c|c|c|c|c|}
\hline $\begin{array}{l}\text { Independent } \\
\text { variables }\end{array}$ & $\begin{array}{c}\text { Unstandardized } \\
\text { B } \\
\end{array}$ & $\begin{array}{l}\text { Standard } \\
\text { error }\end{array}$ & $\begin{array}{c}\text { Standardized } \\
\text { B } \\
\end{array}$ & R Square & $\begin{array}{l}\text { Adjusted } \\
\text { R Square }\end{array}$ & $\begin{array}{l}\text { R Square } \\
\text { Change }\end{array}$ & $\mathrm{F}$ change & $\begin{array}{l}\text { Sig.F } \\
\text { change }\end{array}$ \\
\hline Model 1 & & & & 0.012 & -0.012 & 0.012 & 0.495 & 0.838 \\
\hline Gender & -0.029 & 0.091 & -0.02 & & & & & \\
\hline Age & -0.007 & 0.081 & -0.008 & & & & & \\
\hline Education Level & -0.009 & 0.072 & -0.008 & & & & & \\
\hline \multicolumn{9}{|l|}{ Positional } \\
\hline \multicolumn{9}{|l|}{ Tenure } \\
\hline $0-5$ & 0.2 & 0.164 & 0.135 & & & & & \\
\hline$>5$ & 0.177 & 0.147 & 0.104 & & & & & \\
\hline \multicolumn{9}{|l|}{ Organizational } \\
\hline \multicolumn{9}{|l|}{ Tenure } \\
\hline $0-5$ & -0.242 & 0.235 & -0.12 & & & & & \\
\hline$>5$ & -0.027 & -0.027 & -0.011 & & & & & \\
\hline Model 2 & & & & 0.118 & 0.084 & 0.106 & 8.451 & 0.000 \\
\hline Gender & -0.126 & 0.088 & -0.084 & & & & & \\
\hline Age & 0.002 & 0.078 & 0.002 & & & & & \\
\hline Education Level & -0.013 & 0.069 & -0.011 & & & & & \\
\hline \multicolumn{9}{|l|}{ Positional } \\
\hline \multicolumn{9}{|l|}{ Tenure } \\
\hline $0-5$ & 0.159 & 0.156 & 0.108 & & & & & \\
\hline$>5$ & 0.209 & 0.14 & 0.123 & & & & & \\
\hline \multicolumn{9}{|l|}{ Organizational } \\
\hline \multicolumn{9}{|l|}{ Tenure } \\
\hline $0-5$ & -0.186 & 0.224 & -0.092 & & & & & \\
\hline$>5$ & 0.035 & 0.233 & 0.015 & & & & & \\
\hline Empowerment & 0.004 & 0.065 & 0.005 & & & & & \\
\hline $\begin{array}{l}\text { Competence } \\
\text { Development }\end{array}$ & -0.053 & 0.068 & -0.064 & & & & & \\
\hline Fair Rewards & -0.15 & 0.054 & $-.181 * * *$ & & & & & \\
\hline $\begin{array}{l}\text { Information } \\
\text { Sharing }\end{array}$ & 0.294 & 0.059 & $.371 * * *$ & & & & & \\
\hline
\end{tabular}

Notes: $* \mathrm{p}<.05 ; * * \mathrm{p}<.01 ; * * * \mathrm{p}<.001$

\section{DISCUSSION, LIMITATIONS, AND IMPLICATION OF THE STUDY}

This study has empirically investigated the impact of four corporate culture dimensions on affective, continuance, and normative commitment among Kuwaiti employees' organizational commitment in the banking sector. 
While our findings do not differ substantially from those obtained in previous studies, our results provide a quite compelling support for the influence of corporate culture dimensions on organizational commitment. Seven of the twelve hypotheses were fully supported and confirmed previous studies whereby variables have been positively and significantly related. In conflict with previous studies, empowerment and fair rewards were significantly but negatively related to continuance and normative commitment which will have several important implications for further research. Another important finding in this paper indicates that there is no relationship between competence development and the three types of organizational commitment, something which will be strongly justified in the following.

As shown in Table 5, empowerment was found to be positively and significantly related to the affective component of organizational commitment. This means that the greater the freedom and autonomy of Kuwaiti employees to handle their tasks and participate in decision making, the more they are emotionally committed to their organizations. This finding is consistent with previous studies (Liden et al., 2000; Avolio et al., 2004; Barsoso Castro et al., 2008) confirming that employees are affectively committed to their organizations when they perceive freedom and autonomy as sources of power.

Contrary to most previous studies (Sutton \& Kahn, 1987; Weik, 1988; Bandura, 1989; Spreitzer, 1995), a significant but negative relationship has been found between empowerment and continuance commitment (TsungHsien Kuo et al., 2010). However, there has been some inconsistency in the literature linking empowerment to continuance commitment. Meyer and Allen (1997) indicated that some work behaviors can be negatively related to continuance behavior. In the Kuwaiti culture, in which expats form the majority, employees have strong continuance commitment due to a feeling that they have been "trapped" by the fewer opportunities they have.

The result contradicts the argument that the same work practices that influence affective commitment are more likely to influence normative commitment (Allen and Meyer, 1996). No significant relationship was found between empowerment and normative commitment. The feeling of obligation to stay within the organization is closely related to the Kuwaiti employees' cultural backgrounds. Providing more autonomy and task variety may negatively influence a Kuwaiti employee who would prefer to be praised rather than to work more hours or increase his responsibilities.

Of the four corporate culture dimensions examined in this research, and inconsistent with most previous studies, competence development was found to have no significant relationship with the three components of commitment. Meyer and Smith (2000), in support of our findings, found that employees' evaluation of training practices was not found to contribute, directly or indirectly, to the prediction of commitment. Also, Joo and Shim (2010) found no significant relationship between competence and organizational commitment, contrary to previous results that found direct and indirect impacts of competence on organizational development. A possible explanation of this result is that, regardless of the development of Kuwaiti employees' capabilities and skills, we believe that a nationalization policy of hiring more Kuwaiti employees than expats makes them less motivated to build their competencies.

Results also demonstrated that fair rewards are significantly and positively related to both affective and continuance commitment. Gellatly et al. (2009), in their study on the HRM practices and organizational commitment profiles and in support of our findings, found that reward practices significantly increased employees' emotional attachment to the organization. Malhotra et al. (2007), on the other hand, found that pay satisfaction has a significant and positive effect on continuance commitment. Also, an unexpected and surprising finding negatively associated fair rewards with normative commitment. The explanation for that could be the presence of national cultural influence on how Kuwaiti employees value their job from a prestigious angle regardless of the level of their pay Caldwell et al. (1990) support this finding in their study on building organizational commitment within US firms. They asserted that a clear formal reward system may undermine normative commitment.

In corroboration with previous studies (Campbell, 2000; Giauque et al., 2010; Wong et al., 2009; Kelloway and Barling, 2000), a significant and positive relationship was found between information sharing and affective, continuance and normative commitment. Many researchers (Salancik, 1977; Caldwell et al., 1990; van den Hooff and de Ridder, 2004) pointed out that the more employees receive information about their job and the working 
environment, the more they are likely to be committed to the organization. Sharing information with employees has led to these positive and significant relationships and created a mutual positive feeling about the organization. Several limitations of this research highlight important avenues for future research. Firstly, variables were measured using self-report data which raises the possibility of shared response/social desirability bias in the relations among the variables. Secondly, our sample was drawn only from the Kuwaiti banking industry which may have limitations for generalization to other sectors of the economy. The sample is also based on a specific Arab country, Kuwait, which explains that the rejection of some hypotheses is due to the differences between the cultures of the literature review countries and the sample country. Thirdly, a major conceptual limitation is the focus on four corporate culture dimensions only. There are probably other dimensions such as team orientation, person-fit organization, innovation and risk taking that might have a significant impact on organizational commitment.

This study reveals many practical implications for further research. While most of our findings are consistent with previous studies, researchers are challenged to delve deeper into the complex relationship between corporate culture dimensions and organizational commitment since many of the studies have been conducted in Western societies; thus, the findings can be useful in future comparative studies. A replication of our study in other Arab countries with either the same corporate culture dimensions developed earlier or extended ones could reveal whether our results are country-specified or may be generalized to other countries.

\section{AUTHOR INFORMATION}

Michel Zaitouni is an assistant professor of management at the College of Business at the Gulf University for Science and Technology (GUST) in Kuwait. Research interests include Employees' commitment, Leadership style, Human Resource Management, and change management. E-mail: Zaitouni.M@ gust.edu.kw

Nabeel Sawalha is an assistant professor of international business/management at the Gulf University for Science is and Technology (GUST) in Kuwait since 2008. Formerly, he worked in IBM \& AT\&T for 15 years in different divisions in the telecom industry in Tampa, Florida. Areas of research interests include; International Human Resource development, FDI and Economic Development, and Global Mergers and Acquisitions. E-mail: Sawalha.n@gust.edu.kw (Corresponding author)

Adil ElSharif is currently an assistant professor of finance at the College of Business at the Gulf University for Science and Technology (GUST) in Kuwait. Areas of research interests include; International Human Resource development, FDI and Economic Development, International finance, and exchange rate policies. E-mail: ElSharif.A@ gust.edu.kw

\section{REFERENCES}

1. Abbott, F., White, F., and Charles, M. (2005). Linking values and organizational commitment: A correlational and experimental investigation in two organizations. Journal of Occupational and Organizational Psychology, 78, 531-551.

2. Adams, J. (1965). Inequity in Social Exchange. Advances in Experimental Social Psychology 2nd ed. L. Berkowitz, New York: Academic Press, pp. 267-99.

3. Ahmad, K.Z. and Bakar, R.A. (2003). The association between training and organizational commitment among white-collar workers in Malaysia. International Journal of Training and Development, 7(3), 166185 .

4. Al-Emadi, M., Marquardt, M. (2007). Relationship between employees' beliefs regarding training benefits and employees' organizational commitment in a petroleum company in the State of Qatar. International Journal of Training and Development, 11(1), 49-70.

5. Allen, D.G., Shore, L.M. and Griffith, R.W. (2003). The role of perceived organizational support and supportive human resource practices in the turnover process. Journal of Management, 29(1), 99-118.

6. Allen, N.J. and Meyer, J.P. (1996). Affective, continuance, and normative commitment to the organization: An examination of construct validity. Journal of Vocational Behavior, 49(3), 252-76.

7. Appelbaum, E., Bailey, T., Berg, P., and Kalleberg, A.L. (2000). Manufacturing advantage: Why highperformance work systems pay off. Economic Policy Institute, Ithaca, NY: Cornell University Press. 
8. Armstrong-Stassen, M. and Schlosser, F. (2008). Benefits of a supportive development climate for older workers. Journal of Managerial Psychology, 23(4), 419-437.

9. Ashkanasy, N.N., Wilderom, C., and Peterson, M.F. (eds) (2000). The Handbook of Organizational Culture and Climate. Newbury Park, CA: Sagame.

10. Avolio, B.J., Zhu, W., Koh, W. and Bhatia, P. (2004). Transformational leadership and organizational commitment: Mediating role of psychological empowerment and moderating role of structural distance. Journal of Organizational Behavior, 25(8), 951-68.

11. Bandura, A. (1989). Human agency in social cognitive theory. American Psychologist, 40, $1175-84$.

12. Barnard, M.E. and Rodgers, R.A. (2000). How are internally oriented HRM policies related to highperformance work practices? Evidence from Singapore. The International Journal of Human Resource Management, 11, 1017-46.

13. Castro, B., Perinan, V., and Bueno, C. (2008). Transformational leadership and followers' attitudes: The mediating role of psychological empowerment. International Journal of Human Resource Management, 19(10), 1842-1863.

14. Bhatnagar, J. (2005). The power of psychological empowerment as an antecedent to organizational commitment in Indian managers. Human Resource Development International, 8, 419-433.

15. Bartlett, K.R. (2001). The relationship between training and organizational commitment: A study in the health care field. Human Resource Development Quarterly, 12(4), 335-352.

16. Buck, J. and Watson, J. (2002). Retaining staff employees: The relationship between human resources management strategies and organizational commitment. Innovative Higher Education, 26 (3), 175-193.

17. Caldwell, D.F., Chatman, J.A., and O'Reilly, C.A. (1990). Building organizational commitment: A multifirm study. Journal of Occupational Psychology, 63, 245-261.

18. Campbell, D.J. (2000). The proactive employee. Academy of Management Executive, 14(3), 52-66.

19. Carson, K., Carson, P., Row, C., Birkenmeier, B., Phillips, J. (1999). Four commitment profiles and their relationship to empowerment, service recovery, and work attitude. Public Personnel Management, 28 (1), 1.

20. Cook, W. (1994). Employee participation programs, group-based incentives, and company performance: A union-non-union comparison. Industrial and Labour Relations Review, 47(4), 594-609.

21. Currall, S.C., Towler, A.J., Judge, T.A., \& Kohn, L. (2005). Pay satisfaction and organizational outcomes. Personnel Psychology, 58(3), 613-640.

22. De Brentani, U. and Kleinschmidt, E.J. (2004). Corporate culture and commitment: Impact on performance of international new product development programs. Journal of Product Innovation Management, 21(5), 309-333.

23. Eby, L., Freeman, D., Rush, M. and Lance, C. (1999). Motivational bases of affective organizational commitment: A partial test of an integrative theoretical model. Journal of Occupational and Organizational Psychology, 72, 463-483.

24. Eisenberger, R., Huntington, R., Hutchison, S. and Sowa, D. (1986). Perceived organizational support. Journal of Applied Psychology, 71(3), 500-507.

25. Finegan, J. (2000). The impact of person and organizational values on organizational commitment. Journal of Occupational and Organizational Psychology, 73(2), 149-169.

26. Folger, R. and Konovsky, M.A. (1989). Effects of procedural and distributive justice on reactions to pay raise decisions. Academy of Management Journal, 32(1), 115-130.

27. Gagné, M. and Deci, E.L. (2005). Self-determination: Theory and work motivation. Journal of Organizational Behavior, 26 (4), 331-362.

28. Garr, M. (1998). Organizational culture as a predictor of organizational commitment. Dissertation Abstracts International, 58, 8-B, 4500.

29. Gellaty, I.R., Hunter, K.H., Currie, L.G., and Irving, P.G. (2009). HRM practices and organizational commitment profiles. The International Journal of Human Resource Management, 20(4), 869-884.

30. Giauque, D., Resenterra, F. and Siggen, M. (2010). The relationship between HRM practices and organizational commitment of knowledge workers. Facts obtained from Swiss SMEs. Human Resource Development International, 13(2), 85-205.

31. Gold, M. (2001). Breaking all the rules for recruitment and retention. Journal of Career Planning \& Employment, 61(3), 6-8. 
32. Gomez-Mejia, L.R., Balkin, D.B. and Cardy, R.L. (1995). Managing Human Resources. Englewood Cliffs, NJ: Prentice-Hall, Inc.

33. Gopinath, C. and Becker, T.E. (2000). Communication, procedural justice, and employee attitudes: Relationships under conditions of divestiture. Journal of Management, 26(1), 63-83.

34. Grover, S. and Crooker, K. (1995). Who appreciates family-responsive human practices: The impact of family-friendly practices on the organizational attachment of parents and nonparents. Personnel Psychology, 48, 271-288.

35. Guzley, R.M. (2001). Organizational climate and communication climate: Predictors of commitment to the organization. Management Communication Quarterly, 5(4), 379-402.

36. Guzzo, R. and Noonan, K. (1994). Human resource practices as communications and the psychological contract. Human Resource Management, 33(3), 447-462.

37. Iles, P., Mabey, C. and Robertson, I. (1990). HRM practices and employee commitment: Possibilities, pitfalls and paradoxes. British Journal of Management, 1(3), 147-157.

38. Janssen, O. (2004). The barrier effect of conflict with superiors in the relationship between employee empowerment and organizational commitment. Work \& Stress, 18(1), 56-65.

39. Joo B. and Shim, J. (2010). Psychological empowerment and organizational commitment: The moderating effect of organizational learning culture. Human Resource Development International, 13(4), 425-441.

40. Kelloway, E.K and Barling, J. (2000). Knowledge work as organizational behavior, Framework paper 0003, Queen's Management Research Center for Knowledge-Based Enterprises, Kingston, Canada, available at: www.business.queensu.ca/kbe, accessed October 2002.

41. Koys, D.J. (1988). Human resource management and a culture of respect: Effects of employees' organizational commitment. Employee Rights and Responsibilities Journal, 1(1), 57-68.

42. Koys, D.J. (1991). Fairness, legal compliance, and organizational commitment. Employee Rights and Responsibilities Journal, 4(4), 283-291.

43. Landau, J. and Hammer, T.H. (1986). Clerical employees' perceptions of intraorganizational career opportunities. Academy of Management Journal, 29 (2), 385-404.

44. Laschinger, H.K.S., Finegan, J., and Shamian, J. (2001). The impact of workplace empowerment, organizational trust on staff nurses' work satisfaction and organizational commitment. Health Care Management Review, 26 (3), 7-23.

45. Lawler, E.E., Morhman, S.A. and Ledford, G.E. (1992). Practices and results in Fortune 1000 companies. Employee involvement and TQM. San Francisco, CA: Jossey-Bass Publishers, pp. 9-40.

46. Leana, C.R. and Florkowski, G.W. (1992). Employee involvement programs: Integrating psychological theory and management practice. In G. Ferris (ed.), Research in Personnel and Human Resources Management, 10, Greenwich, CT: JAI Press.

47. Liden, R.T., Wayne, S.J. and Sparrowe, R.T. (2000). An examination of the mediating role of psychological empowerment on the relations between the job, interpersonal relationships, and work outcomes. Journal of Applied Psychology, 85(3), 407-416.

48. Liu, A.M.M., Chiu, W.M., and Fellows, R. (2007). Enhancing commitment through work empowerment. Engineering, Construction and Architectural Management, 14(6), 568 - 580.

49. Malhotra, N., Pawan Budhwar, P. and Prowse, P. (2007). Linking rewards to commitment: an empirical investigation of four UK call centres. International Journal of Human Resource Management, 18(12), 2095-2127.

50. McElroy, J.C. (2001). Managing workplace commitment by putting people first. Human Resource Management Review, 11(3), 327-335.

51. McKinnon, J., Harrison, G., Chow, C. and Wu, A. (2003). Organizational culture: Association with commitment, job satisfaction, propensity to remain and information sharing in Taiwan. International Journal of Business Studies, 11(1), 25-44.

52. Meyer, J.P. and Allen, N.J. (1997). Commitment in the Workplace: Theory, Research, and Application. Thousand Oaks, CA: Sage.

53. Meyer, J.P. and Smith, C.A. (2000). HRM practices and organizational commitment: Test of a mediation model. Canadian Journal of Administrative Sciences, 17, 319-331.

54. Meyer, J.P. Allen, N.J. and Smith, C.A. (1993). Commitment to organizations and occupations: Extension and test of a three-component conceptualization. Journal of Applied Psychology, 78(4), 538-552. 
55. Meyer, J.P., Becker, T.E., \& Vandenberghe, C. (2004). Employee motivation and commitment: A conceptual analysis and integrative model. Journal of Applied Psychology, 89, 991-1007.

56. Meyer, J.P., Stanley, D.J., Herscovitch, L. and Topolnytsky, L. (2002). Affective, continuance, and normative commitment to the organization: A meta-analysis of antecedents, correlates, and consequences. Journal of Vocational Behavior, 61(1), 20-52.

57. Mondy, R.W., Noe, R.M. and Premeaux, S.R. in collaboration with Mondy, J.B. (2002). Human Resource Management 8th ed. Upper Saddle River, NJ: Prentice Hall.

58. Motowildo, S.J. (1988). Predicting sales turnover from pay satisfaction and expectation. Journal of Applied Psychology, 68, 484-489.

59. Malik, O., Abbas, Q., Kiyani, T., Malik, K., and Waheed, A. (2011). Perceived investment in employee development and turnover intention: A social exchange perspective. African Journal of Business Management, 5(5), 1904-1914.

60. O’Neill, B. and Adya, M. (2007). Knowledge sharing and the psychological contract: Managing knowledge workers through various stages of employment. Journal of Managerial Psychology, 22(4), 411436.

61. Paik, Y., Parboteeah, K., and Shim, W. (2007). The relationship between perceived compensation, organizational commitment and job satisfaction: The case of Mexican workers in the Korean Maquiladoras. International Journal of Human Resource Management, 18(10), 1768-1781.

62. Paré, G. \& Tremblay, M. (2007). The influence of high-involvement human resources practices, procedural justice, organizational commitment, and citizenship behaviors on information technology professionals' turnover intentions. Group \& Organization Management, 32(3), 326-357.

63. Parker, R. and Kyi, L. (2006). Vertical information sharing in the budgeting process. Accounting, Organizations and Society, 31(1), 27-45.

64. Pfeffer, J. (1994). Competitive Advantage Through People: Unleashing the Power of The Workforce. Boston, MA: Harvard Business School Press.

65. Pfeffer, J. (1995). Producing sustainable advantage through the effective management of people. Academy of Management Executive, 9(1), 55-69.

66. Pfeffer, J. (1998). The Human Equation: Building Profits by Putting People First. Boston, MA: Harvard Business School Press.

67. Pfeffer, J. and Veiga, J.F. (1999). Putting people first for organizational success. Academy of Management Executive, 13 (2), 37-48.

68. Pillai, R., Schriesheim, C. and Williams, E. (1999). Fairness perceptions and trust as mediators for transformational and transactional leadership: A two-sample study. Journal of Management, 25(6), 897.

69. Postames, T., Tanis, M., \& De Wit, B. (2001). Communication and commitment in organizations: A social identity approach. Group Process and Intergroup Relations, 4(3), 227-246.

70. Ritchie, M. (2000). Organizational culture: An examination of its effect on the internalization process and member performance. Southern Business Review, 25, 1-13.

71. Ronde, T. (2001). Trade secrets and information sharing. Journal of Economics and Management Strategy, 10(3), 391-417.

72. Rousseau, D. (1990). Normative beliefs in fund-raising organizations: Linking culture to organizational performance and individual responses. Group and Organization Studies, 15 (4), 448-460.

73. Salancik, G.R. (1977). Commitment and the control of organizational behavior and belief. In Motivation and Work Behavior. R.M. Steers and L.W. Porter (eds.), New York: McGraw-Hill.

74. Sarkar, S. (2009). Employee empowerment in the banking sector. The IUP Journal of Management Research, 8(9), 48-66.

75. Smeenk, S.G.A., Eisinga, R.N., Teelken, J.C., and Doorewaard, J.A.C.M. (2006). The effects of HRM practices and antecedents on organizational commitment among university employees. The International Journal of Human Resource Management, 17 (12), 2035-2054.

76. Smith, C.A. (1995). Human resource practices and policies as antecedents of organizational commitment. $\mathrm{PhD}$ dissertation, Western University.

77. Spreitzer, G.M. (1995). Psychological empowerment in the workplace: dimensions, measurement, and validation. Academy of Management Journal, 38 (5), 1442-65.

78. Stum, D.L. (1999). Maslow revisited: Building the employee commitment pyramid. Strategy and Leadership, 29(4), 4-9. 
79. Sutton, R.I. and Kahn, R.L. (1987). Prediction, understanding, and control as antidotes to organizational stress. In J. Lorsch (ed.), Handbook of Organizational Behavior. Englewood Cliffs, NJ: Prentice-Hall, pp. 272-85.

80. Taylor, S., Levy, O., Boyacigiller, N. and Beechler, S. (2008). Employee commitment in MNCs: Impacts of organizational culture, HRM and top management orientations. International Journal of Human Resource Management, 19 (4), 501-527.

81. Tekleab, A.G., Bartol, K.M. and Liu, W. (2005). Is it pay levels or pay raises that matter to fairness and turnover? Journal of Organizational Behavior, 26, 899-921.

82. Thornhill, A., Lewis, P. and Saunders, M.N.K. (1996). The role of employee communication in achieving commitment and quality in higher education. Quality Assurance in Education, 4(1), 12-20.

83. Thorpe, R. (2000). Reward Strategy, in Thorpe, R. and Homan G. (eds.), Strategic Reward Systems. Financial Times Prentice Hall.

84. Tremblay, M., Rondeau, A. and Lemelin, M. (1997). La Mise en Oeuvre de Pratiques Innovatrices de Gestion des Ressources Humaines a-t-elle une Influence sur la Mobilisation, GRH face a crise: GRH en crise? Montreal: Presses HEC, 1997, pp. 97-109.

85. Trevor, C.O., Gerhart, B. and Boudreau, J.W. (1997). Voluntary turnover and job performance: Curvilinearity and the moderating influences of salary growth and promotions. Journal of Applied Psychology, 82(1), 44-61.

86. Trombetta, J.J. \& Rogers, D.P. (1988). Communication climate, job satisfaction, and organizational commitment: The effect of information adequacy, communication openness and decision participation. Management Communication Quarterly, 1(14), 494-514.

87. Tsui, A.S., Pearce, J.L., Porter, L.W. and Hite, J.P. (1995). Choice of employee-organization relationship: Influence of external and internal organizational factors. In G.R. Ferris (ed.), Research in Personnel and Human Resource Management. Greenwich, CT: JAI, pp. 117-151.

88. Tsung-Hsien Kuo, Li-An Ho, Chinho Lin, and Kuei-Kuei Lai (2010). Employee empowerment in a technology advanced work environment. Industrial Management \& Data Systems, 110 (1), 24-42.

89. Vandenberghe, C. and Peiro, J. (1999). Organizational and individual values: Their main and combined effects on work attitudes and perceptions. European Journal of Work and Organizational Psychology, 8, 4, 569-581.

90. Van den Hooff, B. and de Ridder, J.A. (2004). Knowledge sharing in context: the influence of organizational commitment, communication climate and CMC use on knowledge sharing. Journal of Knowledge Management, 8(6), 117-130.

91. Wasko, M.M. and Faraj, S. (2005) Why should I share? Examining social capital and knowledge contribution in electronic network of practice. MIS Quarterly, 29(1), 35-57.

92. Weick, K. (1988), "Enacted sensemaking in crisis situations", Journal of Management Studies, 25(4), 30517.

93. Welch, D. and Welch, L. (2006). Commitment for hire? The viability of corporate culture as a MNC control mechanism. International Business Review, 15(1), 14-28.

94. Weng, Q., McElroy, J.C., Morrow, P.C. and Rongzhi, L. (2010). The relationship between career growth on organizational commitment. Journal of Vocational Behavior, 77(3), 391-400

95. Wong, A., Tong, C., and Mula, J. (2009). Knowledge sharing acts as a significant antecedent to organizational commitment in a Confucian culture: A quantitative study of employees in the Hong Kong ICT industry. The 20th Australasian Conference on Information Systems, 2-4 Dec 2009, Melbourne.

96. Wood, S. and DeMenezes, L. (1998). High commitment management in the UK: Evidence from the Workplace Industrial Relations Survey, and Employers' Manpower and Skills Practice Survey. Human Relations, 51(4), 485-515.

97. Yang, Yi-Chun (2011). High-involvement human resource practices, affective commitment, and organizational citizenship behaviors in service setting. The Service Industries Journal, First published on: January 27th, 2011 (iFirst).

98. Young, B.S. and Worchel, S. (1998). Organizational commitment among public service employees. Public Personnel Management, 27(3), 339-349. 
NOTES 